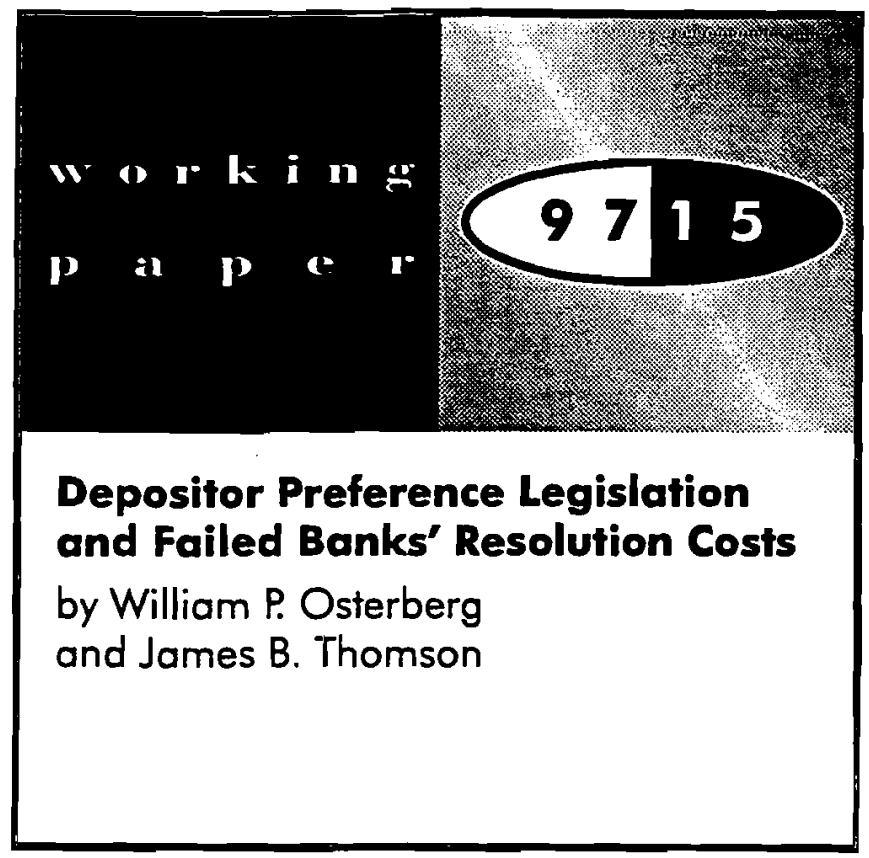




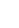


Working Paper 9715

\section{DEPOSITOR PREFERENCE LEGISLATION AND FAILED BANKS' RESOLUTION COSTS}

by William P. Osterberg and James B. Thomson

William P. Osterberg is an economist at the Federal Reserve Bank of Cleveland. James B. Thomson is a vice president and economist with the Financial Services Research Group of the Federal Reserve System, located at the Cleveland Fed. The authors thank James Barth, William Greene, Joseph Haubrich, and Stanley Longhofer for helpful comments and suggestions. Sandy Sterk provided outstanding research assistance.

Working papers of the Federal Reserve Bank of Cleveland are preliminary materials circulated to stimulate discussion and critical comment. The views stated herein are those of the authors and are not necessarily those of the Federal Reserve Bank of Cleveland or of the Board of Governors of the.Federal Reserve System.

Federal Reserve Bank of Cleveland working papers are distributed for the purpose of promoting discussion of research in progress. These papers may not have been subject to the formal editorial review accorded official Federal Reserve Bank of Cleveland publications.

Working papers are now available electronically through the Cleveland Fed's home page on the World Wide Web: http://www.clev.frb.org.

December 1997 



\begin{abstract}
Included in the Omnibus Budget Reconciliation Act of 1993 was a provision that improved the priority of depositors and thus of the FDIC in the event of a depository institution's failure. While intended to reduce the FDIC's cost of resolving commercial bank failures, this provision might have induced general creditors to react so as to offset the intended benefit. Depositor preference legislation (DPL) might also have affected the FDIC's choice of resolution type.

Here we examine the empirical impact of DPL on resolution type and on resolution costs for commercial banks. Given the short time period since the passage of national DPL in 1993, we focus on the impact of state DPL statutes, utilizing call-report data and FDIC data on resolution costs and resolution types for all operating FDIC-BIF insured commercial banks that were closed or required FDIC financial assistance from January 1986 through December 1992. We improve on previous studies by controlling for the endogeneity of book capital and by adjusting for the sample selection bias induced by regulatory closure rules.

We find that DPL has 1) tended to increase, rather than reduce, FDIC resolution costs and 2) induced the FDIC to choose assisted mergers over liquidations. However, the source of the higher resolution costs is unclear and there is no evidence that general creditors reacted by increasing collateralization.
\end{abstract}


On August 10, 1993 Congress passed the Omnibus Budget Reconciliation Act of 1993. Contained in this legislation was a provision that revised the priority of claims on failed depository institutions by making other senior claimants junior to depositors. Congress apparently hoped to reduce Federal Deposit Insurance Corporation (FDIC) losses by thus changing the capital structure of banks to enhance the priority of depositors and thus of the FDIC.

Unlike subordinated debenture holders, however, general creditors of depository institutions can restructure their claims to effectively make them senior to depositors. For example, in response to the implementation of depositor preference laws (DPLs) a general creditor might collateralize her claim. Alternatively, she could shorten the maturity of her claim to increase the probability she could exit before the bank is closed. While there have been theoretical analyses of how DPL should affect the values of various bank claimants, there have been no empirical analyses of whether or not the FDIC's losses have been reduced, or whether general creditors have responded so as to offset the intended benefits to the FDIC. 1

Although little time has passed since the passage of the 1993 legislation some individual states already had DPL in effect. In this paper, we examine the impact on FDIC resolution costs of such state legislation from 1984-1992, extending the empirical analyses of closed-bank resolution cost models by James (1991), Osterberg and Thomson (1995) (henceforth, OT), and Osterberg (1996). The theoretical framework follows Hirschhorn and Zervos (1990) and Osterberg and Thomson (1994), where DPL reduces the value of the FDIC claim unless general creditors undertake some offsetting action. $^{2}$ We also test the hypothesis advanced by some analysts that DPL might influence the FDIC's choice of resolution type, control for the endogeneity of book measures of bank capital, and correct for sample selection bias introduced by regulatory closure rules.

\footnotetext{
${ }^{1}$ See Thomson (1994) for an example of how FDIC losses may increase as a result of depositor preference laws.
} 
The remainder of the paper is as follows. Section. I outlines the depositor preference legislation and the FDIC's implementation of it. Section II reviews the existing literature. The data and the empirical method are presented in III. Our results and conclusions are appear in sections IV and V respectively.

\section{The Legislative Provisions}

Title III of the Omnibus Budget Reconciliation Act of 1993 instituted depositor preference for all insured depository institutions by amending Section 11(d)(11) of the Federal Deposit Insurance Corporation Act [12 U.S.C. 1821(d)(11)]. ${ }^{3}$ The amendment establishes the following priority of payment in the resolution of a failed depository institution:

(1) Administrative expenses of the receiver.

(2) Deposit liabilities.

(3) General or senior liabilities.

(4) Subordinated obligations.

(5) Shareholder claims.

Prior to DPL, general or other senior liabilities had the same priority of payment as deposits. However, regardless of the presence of depositor preference, secured creditors of the failed depository will have their claims satisfied first, up to the amount of the collateral. This implies that general or senior creditors could protect their claim by responding to the passage of DPL by increasing collateral.

Clearly, the value of deposit liabilities and claims lower in the pecking order depends on the interpretation of "administrative expenses of the receiver." On August 13, 1993 the FDIC issued an interim rule which clarified its interpretation of these expenses, indicating that such expenses include "post appointment obligations incurred

2 Birchler (1997) provides a contract-theoretic explanation of the priority structure of bank deposits. 3 At the time national depositor was enacted 29 states had similar laws covering state-chartered banks and 18 had depositor preference statutes covering state-chartered thrift institutions. 
by the receiver as part of the liquidation of an institution." and that "this priority also covers certain expenses incurred prior to the appointment of the receiver." 4 In other words, the receiver (which for most banks and thrifts is the FDIC) may pay expenses it deems to be consistent with the orderly closure of the institution, even if those expenses were incurred prior to the depository's closure. These pre-receivership expenses include. the payment of the institution's last payroll, guard services, data processing services, utilities and lease payments. Examples of expenses that would be excluded are items such as golden parachute claims, severance pay claims, and liabilities arising from the repudiation of contracts.

\section{Related Literature}

The purported impact of DPL is to decrease the FDIC's costs of resolving bank failures. Such costs derive from three sources. First are the losses that reflect the underlying insolvency of the bank. These are the realization of the downside risk associated with a bank's investment and financing decisions. On an economist's extended balance sheet, these losses equal the negative market net worth of the firm (excluding the value of government guarantees). Second are the losses related to forbearance, which are incurred after the depository is no longer economically viable but before it is closed. 5,6 Third are the costs associated with receivership, including administrative and legal expenses. ${ }^{7}$

Several adverse impacts of DPL have been hypothesized. The most frequent has been increased collateralization by nondepositors or general creditors which include

\footnotetext{
${ }^{4}$ See Federal Register (1993). At the time of this writing the FDIC had not issued a final rule on depositor preference.

${ }^{5}$ Although the costs of forbearance have not been explicitly calculated for banks, DeGennaro and Thomson (1996) find that these costs were considerable for thrifts.

${ }^{6} \mathrm{Kane}(1986)$ argues that information, funding, administrative and legal, and political constraints cause bank regulators to adopt suboptimal closure rules. Allen and Saunders (1993) model deposit insurance as a callable perpetual put option. The value of forbearance is the difference between the value of the call option under unconstrained regulatory closure rules and its value under constrained closure rules.

7 For example, expenses for the FDIC's division of liquidation averaged 8.3 percent of collections in 1991 (see the FDIC's 1991 Annual Report). Moreover, at the end of 1992, the FDIC's estimated contingent
} 
include trade creditors, beneficiaries of guarantees, foreign depositors (to the extent that their treatment is different from that of domestic depositors), holders of bankers acceptances, unsecured lenders, landlords, fed funds sellers, and counterparties to various contingent liabilities. Collateralization would move such secured lenders ahead of all depositors in terms of the priority of claims in the event of failure. While collateralization would have this impact even without depositor preference Hirschhorn and Zervos (1990) claim that the new legislation increases the incentive to collateralize. They further conclude that the damage done by DPL to the insurer and the uninsured depositor increases with the degree of collateralization of nondeposit claims and the extent of insolvency.

It has also been claimed that depositor preference would harm smaller community banks and thrifts. Banks with lower levels of capital supposedly would have a harder time floating debt, borrowing federal funds, leasing computers, and renting space. Some banks might be shut out of the derivatives markets or see their credit rating on bankers' acceptance or bank notes downgraded. ${ }^{8}$ Large banks and, in particular, those seen as too-big-to-let fail supposedly would have an enhanced advantage in attracting deposits over $\$ 100,000$ since such deposits may not be seen as being at risk, though the risk would increase for smaller banks with depositor preference. Claims have also been made of a negative impact on market discipline though others claim a positive impact due to the increased risk of loss among nondepositors. ${ }^{9}$

There has been little empirical research on the impact of depositor preference legislation (DPL), despite repeated claims of benefits. Hirschhorn and Zervos (1990) found that, following the passage of state DPL, general creditors of affected savings and loans increased collateralization and interest rates on uninsured certificates of deposits

liability for unresolved legal cases was $\$ 404$ million. Costs of receivership also include losses that arise from the inefficient asset salvage operation of the receiver (see Kane [1990]).

8 See Rehm (1993)

${ }^{9}$ See Kaufman (1997). 
fell. While Osterberg (1996) finds evidence that resolution costs for commercial banks closed in states with DPL were lower than in other states, the exact role played by DPL is unclear. In studies which provide no role for DPL, Bovenzi and Murton (1988), James (1991), and OT model resolution costs as determined by problem assets, risky assets, and core deposits. OT also include proxies for fraud and off-balance sheet risk. Below we will attempt to take into account empirical findings on the determinants of resolution costs and to discern the mechanism through which DPL might play an additional role.

\section{Data and Empirical Methods}

Since the preponderance of bank failures occurred prior to 1993, we choose to analyze the impact of state-level DPLs already in effect. It is notable that state-level DPLs apply to state-chartered institutions which differ along several dimensions from national banks (see Osterberg [1996]). A list of the state depositor preference laws for banks and thrifts can be found the appendix.

The sample includes all operating FDIC-BIF insured commercial banks on December 31, 1992 and those FDIC-BIF insured commercial banks that were closed or required FDIC financial assistance to remain open from January 1, 1986 through December 31, 1992. Quarterly balance sheet and income data for these banks are from the Federal Financial Institution Examination Council's Quarterly Reports of Condition and Income (call reports) from March 31, 1984 through December 31, 1992. Closure data, estimated resolution cost (to the FDIC) and resolution type are from FDIC (1993).

We address three econometric problems with previous studies of closed-bank resolution costs. The first is that these studies usually fail to control for the endogeneity of book capital [see (Maddala (1986) and Thomson (1992)]. The second is that estimates of a single equation model of closed-bank resolution costs suffer from sample selection bias induced by regulatory closure rules [see Barth et al. (1990)]. Finally, these studies fail to control for the endogeneity of the choice of resolution type. In the estimation of 
our empirical model we will econometrically correct for these effects.

Our empirical model focuses on two equations that are estimated sequentially.

$$
\begin{gathered}
\text { 1. RESTYPE }=\alpha_{0}+\sum_{j=1}^{n} \alpha_{j} X_{j n}+e_{i t} \\
\text { 2. RESCOST }=\beta_{0}+\beta_{i} \hat{R} E S T Y P E+\sum_{i=2}^{m} \beta_{i} X_{i t}+u_{i t}
\end{gathered}
$$

In equation (1) the dependent variable equals 0 when failure is resolved by liquidation, which provides no de facto deposit guarantees to uninsured depositors and general creditors and equals 1 otherwise. Prior to the Federal Deposit Insurance Corporation Improvement Act (FDICIA) of 1991 the FDIC could resolve bank insolvencies in one of three ways. First, the FDIC could choose to liquidate the institution, in what is commonly referred to a payout. While there are several different ways to implement a payout the implications for the FDIC, uninsured depositors, and unsecured general creditors are the same for each; they receive no de facto guarantees of their claims and thus are fully exposed to loss. The second way in which the FDIC could resolve an insolvency is through a purchase and assumption transaction (P\&A). Prior to FDICIA, a P\&A typically involved the transfer of all deposits and general creditor obligations to another bank, thereby providing de facto guarantees to senior creditors. The third method has the FDIC infusing capital into an open institution. The net effect of such open-bank assistance (OBA) is the extension of de facto deposit insurance coverage to depositors and general creditors. ${ }^{10}$

The key to understanding how and why DPL might influence the FDIC's choice of resolution type is an outline of the way in which DPL would affect the outcomes to

\footnotetext{
${ }^{10}$ The Competitive Equality Banking Act of 1987 gave the FDIC an intermediate option for handling a failed bank, the bridge bank. Under bridge bank authority (which was expanded by FIRREA 1989) the FDIC can pass the assets and liabilities of the failing bank into a specially chartered National bank which the FDIC can operate for up to three years. The bridge bank option gives the FDIC more flexibility in resolving closed banks by extending the time it has to weigh its alternative resolution options.
} 
various creditor claims under different types of resolutions. As was noted by Hirschhorn and Zervos (1990), under liquidation and without depositor preference, the FDIC will share with both the uninsured depositors and nondepositors. In an assisted merger, on the other hand, all deposits are covered even without depositor preference and the nondeposit claims are passed on to the acquiring institution. However, with depositor preference the nondeposit claims may not be passed on.

From this analysis, Hirschhorn and Zervos conclude that the only case where depositor preference will unambiguously benefit the FDIC is in an assisted merger (e.g. P\&A), suggesting a positive relationship between DPL and the use of P\&As. Other authors reach different conclusions. Ely (1993), for example, argues that depositor preference would reduce the usage of the 'purchase and assumption' resolution method in which all assets and liabilities are transferred to the new owner. He thus predicts the increased usage of deposit transfers in which only deposits were transferred.

For the estimation of the resolution type equation, we group the OBA banks and the P\&A banks into a single category and estimate equation (1) using probit. ${ }^{11} 12$ Variable definitions are given in Table 2 and the top panel of Table 6 lists the variables included in the resolution type equation. These variables were chosen by stepwise regression with the order shown in the top panel of Table 3 being the order in which the variables were chosen. ${ }^{13}$

The coefficient on our dummy variable for depositor preference status will be negative (positive) if state banks in states with DPL are more likely to be resolved via liquidation (P\&A or OBA). The discussion above also implies that higher levels of COREDEP (and thus lower levels of nondeposit claims) would encourage the use of

\footnotetext{
${ }^{11}$ Application of multinomial probit to (1) is infeasible due to the small number of OBA transactions in our sample. In addition, since the OBA and P\&A have the same implications for senior creditors the choice between them should not be affected by the presence of depositor preference laws.

12 The failure equation probit provides the selectivity condition for the resolution type probit.

${ }^{13}$ A theory of how resolution type is chosen would have at least narrowed the list of variables. However, another important consideration is that the right-hand side variables for the two equations permit identification.
} 
P\&As and OBA. Keeley (1990) claims that COREDEP controls for the franchise (charter) value and is a source of unbooked gains. Buser, Chen, and Kane (1981) argue that the FDIC will try to mimimize its losses by closing banks in a manner that preserves the value of the charter. We include as an explanatory variable the predicted value of net worth/total assets generated as described below.

Equation (2) is the resolution cost equation. Since little case-specific data on receivership costs is available, let alone the marginal receivership cost for each closed institution, we measure the dependent variable as the total resolution cost. The list of independent variables extends that in OT. We estimate (2) by weighted-least squares and, as is the case for all the equations, regressors are dated 4 to 6 months before the closure date.

RESCOST is the FDIC's estimated resolution cost as published by the FDIC (1993, Appendix A). OREO, PD30, and PDNA are proxy variables for asset quality. Given that the primary sources of unbooked losses are losses on the asset portfolio, on-book problem assets should be a good proxy for these unbooked losses. As discussed above, COREDEP controls for the franchise value and is a source of unbooked gains. UNCOL is a proxy for problem assets not reported by the bank. As Bovenzi and Murton (1988) note, distressed banks have incentives to cover up the amount of problem assets in their portfolio. One method for doing this is to book income on a nonperforming loan to prevent it from being classified as past due or nonaccrual. This implies that UNCOL would be positively correlated with unbooked losses. Book equity plus reserves, CAPPRED, represent the cushion between the value of assets and the promised payments to debt holders. NCRASST is included as a proxy for portfolio risk.

OT included dummy variables for filer types (filer type is related to size) and size categories defined by the dummies DSZ1-DSZ6. We replace these categories by LNASST, a decision supported by a standard specification test, and add variables 
capturing regional variation in banking conditions. ${ }^{14}$

Predicted resolution type is also included: if the FDIC minimizes resolution cost (subject to various legal and regulatory constraints) through its choice of resolution type, DPL's impact on resolution cost may be partly absorbed through the inclusion of predicted resolution type in the resolution cost equation. We also include a predicted level of net worth. Predicted values for both resolution type and the level of net worth are included to control for their endogeneity. The standard errors are adjusted as described below.

Although (1) and (2) are the main equations of interest, we first estimate two other equations and assume that the model has a recursive structure. The first is for net worth with book capital being predicted by bank balance sheet variables. The second equation is a probit for failure (bank closure). As in Barth, Bartholomew, and Bradley (1990) we construct an instrument to control for sample-selection bias in the resolutiontype and resolution-cost equations. Following Thomson [1992] the predicted value of book capital from the net worth equation is included as a proxy for net worth on the right-hand side of the closure, resolution-type, and resolution-cost equations.

The inclusion of the predicted value of net worth on the right-hand side of the other three equations and the inclusion of a predicted value of resolution type on the right-hand side of the resolution cost equation requires that the standard errors be adjusted, following Murphy and Topel (1985). The implementation of this procedure is discussed in the appendix. The four equations are estimated using LIMDEP 6.0. First the net worth equation is estimated in both ratio and levels form. Then the failure and resolution type equations are estimated as an ordered probit (the failure equation provides the selection rule for resolution type) including predicted values of the net

\footnotetext{
${ }^{14}$ In addition, the significance of individual filer type dummies is eliminated when federal funds variables are included.
} 
worth ratio on the right-hand sides. ${ }^{15}$ Finally, the resolution cost equation is estimated with weighted-least squares (dividing by the square root of total assets), including the predicted level of net worth and the predicted resolution type on the right-hand side, with the failure equation providing a selection rule.

\section{Results}

Tables 3, 4, and 5 present the results for the net worth equations and the closure equation, respectively. The interested reader is referred to Thomson (1992) for an interpretation of the coefficients of these equations.

Table 6 contains the estimated coefficients for equation (1) (resolution type) from the ordered probit. The negative and significant coefficient on LPRBSAD indicates that the FDIC is more likely to liquidate a closed bank when the value of banking franchises are low. The negative and significant coefficient on the northeast dummy, DUMNES, is consistent with the this explanation.

The relationship between the southwest dummy variable and resolution type is more complex. Prohibition of branching in Texas lead to the creation of large multibank holding companies (BHCs). The collapse of the depository institutions sector in the Southwest included FDIC resolution of five of the eight largest Texas BHCs and the death-bed acquisition of two of the other three large Texas BHCs by out-of-state banking organizations. Finally, despite the economic problems in Southwest in the mid-1980s this region was expected to be a high growth region in terms of both population and income. Hence, the positive and significant sign on DUMSW appears to be controlling for constraints faced by the FDIC in resolving the insolvency of large multi-bank BHCs and the value of Texas banking franchises to out-of-state BHCs.

DSBRNCH, the dummy variable for branching regulations, is negative and significant. Given that the number of potential acquirers for a closed bank is higher in

\footnotetext{
${ }^{15}$ Although the failure and resolution type equations together constitute an ordered probit (with neither dependent dummy variable appearing on the right-hand side of the other equation), LIMDEP's bivariate probit routine could be utilized.
} 
states without intrastate branching restrictions we would expect DSBRNCH be positively related to the use of the purchase and assumption resolution option (and other types of assisted mergers).

Thomson (1992) finds that the probability a bank is closed is inversely related to its capitalization. This suggests that closed banks with high book capital ratios are likely to have high levels of unbooked losses. ${ }^{16}$ Another important source of unbooked losses on a bank's balance sheet is other real estate owned, which is essentially repossessed properties. Hence, the negative and significant coefficients on CAPTAPS and OREOAS are consistent with the FDIC's choice of a liquidation when faced with large contingent liabilities.

The positive and significant coefficients on LNASST and CORDEPA are consistent with expectations. A positive and significant relationship between size and de facto insurance of all senior claimants (uninsured depositors and general creditors) is consistent with the too-big-to-let fail doctrine practiced prior to FDICIA (see Carnell [1993] and Todd and Thomson [1991]). The positive and significant coefficient on CORDEPA is consistent with the model of Buser et al. (1981).

The results from equation (1) suggest that DPL induces the FDIC to choose P\&As. There are two possible explanations for the positive coefficient on DPL. First, general creditors in banks subject to depositor preference might successfully exit the bank or effectively collateralize their exposure before the bank is closed, thereby raising the cost of a liquidation vis-à-vis purchase and assumption and open-bank assistance transactions. Hirschhorn and Zervos (1990) provide evidence of this type of general creditor response in their study of thrifts. Second, as in Kane (1986), constraints faced by the FDIC may cause it to choose the resolution option that jointly minimizes its fiduciary, political, and other costs associated with resolving the closed bank. In a liquidation the FDIC would have to strictly observe depositor preference, whereas, in

${ }^{16}$ This effect may be partially absorbed by taking account of the selection rule provided by the closure equation. 
P\&A and OBA it could choose to ignore it. Hence, DPL could increase the nonfiduciary costs to the FDIC associated with liquidations, increasing the relative attractiveness the its alternative failed-bank resolution options.

Estimated coefficients for equation (2) from the selection model appear in table 7 and 8. Table 9 compares these results with those found in OT and Osterberg (1996) and thus indicates the importance of correcting for sample selection bias induced by regulatory closure rules. Estimated coefficients on the proxy variables for unbooked losses and gains in closed bank portfolios are larger (in absolute value) than those in previous studies, and in many cases the differences are statistically significant.

The coefficient on our instrument for book capital, CAPPRED, is negative and significantly different from both zero and $(-1)$. This corroborates the findings of James (1991) and OT of significant unbooked losses on the balance sheets of failed banks. On the other hand, unlike James (1991) and OT, income earned but not received, UNCOL, was not signficant at the 10 percent level although the sign of its impact was positive. However, the coefficient on UNCOL is positive and significant in when equation (2) omits measures of fed funds sold, fed funds purchased and other borrowed money as regressors.

PDNA and OREO are included in equation (2) as proxies for asset quality. Both of these control for unbooked losses and have positive and significant coefficients. As in OT we find loans to insiders and portfolio risk to be positively and significantly related to resolution costs. Moreover, as in Osterberg (1996) we find that a positive and significant coefficient on FFSOLD. This is consistent with banks in depressed regional economies using fed funds as the residual asset item in managing the asset side of their balance sheet. Hence, FFSOLD may be proxying for the quality of the loan portfolio.

Off-balance sheet activities are negatively and significantly related to resolution costs. Similar results are found by OT when OBS is split into off-balance sheet loan items and other off-balance sheet activities. A negative and significant coefficient on 
OBS is consistent with the market discipline hypothesis of Boot and Thakor (1991) and the hypothesis that banks use derivative contracts to hedge against on-balance-sheet risk. $^{17}$

In Table 8, as in OT, bank size remains an important determinant of resolution costs. The positive and significant coefficient on LNASST is consistent with higher FDIC administrative and legal expenses for resolving large banks. The results are qualitatively the same found when dummy variables are used to proxy for size.

Resolution type does not have a significant impact on resolution cost. The coefficients on predicted resolution type from equation (1) (PRESTYPE), and its product with COREDEP, (ICORE23), are statistically insignificant. This is consistent with the hypothesis that the FDIC chooses resolution type to minimize resolution cost.

The positive and significant coefficient on the depositor preference dummy in the resolution cost equation is inconsistent with the hypothesis that depositor preference laws lower the FDIC's costs. However, we cannot distinguish the source of the higher resolution costs. The positive coefficient on DPL is consistent with either the FDIC adopting resolution options that provided de facto guarantees of all senior creditors found in equation (1) or with offsetting responses by general creditors. Which of these explanations holds has important implications for the efficacy of the national depositor preference laws. If higher resolution costs associated with DPL are driven by FDIC behavior then reforms in FDICIA (1991), such as prompt corrective action and the constraints on too-big-to-let fail, could eliminate or reverse this effect of DPL. If, on the other hand, general creditor behavior is driving the positive coefficient on DPL then the net effect of the national depositor preference may be to increase FDIC closed-bank resolution costs.

FFPURCH and OBM are included in equation (2) as proxies for general creditor claims. Ceteris paribus, higher levels of FFPURCH, as unfunded liabilities, would be

${ }^{17}$ See Avery and Berger (1991) and Koppenhaver and Stover (1991). 
expected to increase costs. However, the negative and significant coefficient on FFPURCH and the negative coefficient on OBM are not consistent with general creditors increasing their collateralization. FFPURCH includes repurchase agreements which are collateralized so that we might have expected the average collateralization of this category to rise. One alternative explanation is similar to that suggested by the coefficient on OBS, namely that FFPURCH and OBM provide market discipline and that banks able to utilize these funding channels have lower unbooked losses than we have captured with our call report proxies for balance sheet quality.

\section{Conclusion and Policy Implications}

An examination of the period preceding the passage of the national depositor preference law provides no evidence to support claims that depositor preference will result in lower FDIC resolution costs. On the contrary, we find a positive relationship between depositor preference and the cost of resolving a closed bank. We also find a positive relationship between the presence of depositor preference laws and the use of P\&A and OBA transactions, both of which minimize the benefit to the FDIC from depositor preference. These results are largely consistent with Kane's (1986) analysis of FDIC behavior.

The sample period we study precedes the implementation of FDICIA (1991) which placed limits on the FDIC's ability to extend de facto guarantees to uninsured depositors and general creditors. ${ }^{18}$ As a result, the FDIC's choice of resolution type may no longer be affected by depositor preference laws. On the one hand, this provision of FDICIA may induce general creditors to increase collateralization or shorten maturities. On the other hand, if FDICLA's prompt corrective action provisions result in the closure of capital deficient but book solvent banks, then depositor preference should have no impact on FDIC resolution costs.

\footnotetext{
${ }^{18}$ See Carnell (1993) for a discussion of FDICIA.
} 


\section{References}

Allen, L., and A. Saunders, 1993, "Forbearance and the Valuation of Deposit Insurance as a Callable Perpetual Put," Journal of Banking and Finance 16 (June), 629-643.

Avery, R. B., and A. N. Berger, 1991, "Loan Commitments and Bank Risk Exposure," Journal of Banking and Finance 15 (September), 173-192.

Barth, J. R., P. F. Bartholomew, and M. G. Bradley, 1990, "Determinants of Thrift Institution Resolution Costs," Journal of Finance 45 (July), 731-754.

Birchler, Urs W., 1997, "Bancruptcy priority for bank deposits: A contract theoretic explanation," Discussion Paper no. 9709, Department of Economics, University of St. Gallen, Switzerland, May.

Boot, A. W. A., and A. V. Thakor, 1991, "Off-Balance-Sheet Liabilities, Deposit Insurance, and Capital Requirements," Journal of Banking and Finance 15 (September), 825-846.

Bovenzi, J. F., and A. J. Murton, 1988, "Resolution Costs of Bank Failures," FDIC Banking Review 1 (Fall), 1-11.

Brown, R. A., and S. Epstein, 1992, "Resolution Costs of Bank Failures: An Update of the Historical Loss Model," FDIC Banking Review 5 (Spring/Summer), 1-16.

Buser, S. A., A. H. Chen, and E. J. Kane, 1981, "Federal Deposit Insurance, Regulatory Policy, and Optimal Bank Capital," Journal of Finance 36 (September), 775-787.

Carnell, R. S., 1993, "A Partial Antidote to Perverse Incentives: The FDIC Improvement Act of 1991," Annual Review of Banking Law 12, 317-321.

DeGennaro, R. P., and J. B. Thomson, 1996, "Capital Forbearance and Thrifts: Examining the Costs of Regulatory Gambling," Journal of Financial Services Research 10 (September), 199-211.

Ely, Bert. "Surprise Congress Just Enacted the Core Banking System, "American Banker, vol. 158, September 21, 1993, p.24.

Federal Deposit Insurance Corporation, 1993, "Failed Bank Cost Analysis: 1986-1992," Washington, D.C. (FDIC).

Federal Register, vol. 58, no. 155, Friday, August 13, 1993, pp. 43069-43070.

Greene, W.H., 1993, Econometric Analysis, New York, MacMillan. 
Hirschhorn, E., and D. Zervos, 1990,"Policies to Change the Priority of Claimants: The Case of Depositor Preference Laws," Journal of Financial Seroices Research 4, 1990, 111 25.

James, C., 1991, "The Losses Realized in Bank Failures," Jourmal of Finance 46 (September), 1223-1242.

Kane, E. J., 1986, "Appearance and Reality in Deposit Insurance Reform," Journal of Banking and Finance 10, 175-188.

Kane, E. J., 1990, "Principal-Agent Problems in S\&L Salvage, Journal of Finance 45 (July), 755-764.

Kaufman, George G., 1997, "The New Depositor Preference Act: Time Inconsistency in Action," Managerial Finance, 23, 56-63.

Keeley, M. C., 1990, "Deposit Insurance, Risk, and Market Power in Banking," American Economic Review 80 (December), 1183-1200.

Koppenhaver, G. D., and R. D. Stover, 1991, "Standby Letters of Credit and Bank Capital: Evidence of Market Discipline," Proceedings from a Conference on Bank Structure and Competition, Federal Reserve Bank of Chicago (May), 373-394.

Maddala, G.S., 1986, "Econometric Issues in the Empirical Analysis of Thrift Institutions' Insolvency and Failure," Working Paper, University of Florida.

Murphy, K. M., and R. H. Topel, 1985, "Estimation and Inference in Two-Step Econometric Models, Journal-of-Business-and-Economic-Statistics; 3(4), 370-79.

Osterberg, W. P., 1996, "The Impact of Depositor Preference Laws," Economic Review, Federal Reserve Bank of Cleveland (Quarter 3), 2-11.

Osterberg, W. P., and J. B. Thomson, 1994, "Depositor Preference and the Cost of Capital for Insured Depository Institutions," Federal Reserve Bank of Cleveland, Working Paper 9404, April.

Osterberg, W. P., and J. B. Thomson, 1995, “Underlying Determinants of Closed-Bank Resolution Costs," in The Causes and Costs of Depository Institution Failures, Kluwer.

Rehm, B. A., 1993, 'Budget Provision Threatens Credit of Weak Banks," American Banker, vol. 158, no. 148 (August 4, 1993), pp.1.

Thomson, J. B., 1992, "Modeling the Bank Regulator's Closure Option: A Two-Step Logit Regression Approach," Journal of Financial Services Research 6, 5-23. 
Thomson, J. B., 1994,"The National Depositor Preference Law," Federal Reserve Bank of Cleveland, Economic Commentary (February 15).

Todd, W. F., and J. B. Thomson, 1991, "An Insider's View of the Political Economy of the Too Big to Let Fail Doctrine," Public Budgeting and Financial Management: An International Journal 3, 547-617. 
State

\begin{tabular}{ll} 
Alaska & $10 / 15 / 78$ \\
Arizona & $9 / 21 / 91$ \\
California & $6 / 27 / 86$ \\
Colorado & $5 / 1 / 87$ \\
Connecticut & $5 / 22 / 91$ \\
Florida & $7 / 3 / 92$ \\
Georgia & 19741 \\
Hawaii & $6 / 24 / 87$ \\
Idaho & 19792 \\
Iowa & $1 / 1 / 70$ \\
Kansas & $7 / 1 / 85$ \\
Louisiana & $1 / 1 / 85$ \\
Maine & $4 / 16 / 91$ \\
Minnesota & $4 / 24 / 90$ \\
Missouri & $9 / 1 / 93$ \\
Montana & 1927 \\
Nebraska & 1909 \\
New Hampshire & $6 / 10 / 91$ \\
New Mexico & $6 / 30 / 63$ \\
North Dakota & $7 / 1 / 87$ \\
Oklahoma & $5 / 26 / 65$ \\
Oregon & $1 / 1 / 74$ \\
Rhode Island & $2 / 8 / 91$ \\
South Dakota & $7 / 1 / 69$ \\
Tennessee & 1969 \\
Utah & 1983 \\
Virginia & $7 / 1 / 83$ \\
West Virginia & $5 / 11 / 81$ \\
& \\
\hline &
\end{tabular}

$10 / 15 / 78$

$9 / 21 / 91$

$6 / 27 / 86$

$5 / 1 / 87$

$5 / 22 / 91$

$7 / 3 / 92$

$6 / 24 / 87$

$1 / 1 / 70$

$7 / 1 / 85$

$4 / 16 / 91$

$4 / 24 / 90$

/1/93

1909

$6 / 10 / 91$

$6 / 30 / 63$

$5 / 1 / 87$

$5 / 26 / 65$

$2 / 8 / 91$

$7 / 1 / 69$

$5 / 11 / 81$
Table 1: State Depositor Preference Legislation for Banks Date Effective

1 : Legislation became effective on either January 1 or July 1.

2: Passed by both houses on July 1 , enactment date unclear.

In other cases when only the year is indicated, neither the month nor the day of enactment is available. 
Table 2: Variable Definitions

BFLIAB

BRKDEP

CAPPRED

CAPTAPS

COREDEP

COREDEPA

DBHC

DPL

DSBRANCH

DUMNES $=1$

DUMSW

EFFICNYS

FFSOLD

FFPURCH

HOTFUNDS

ICORE23

UNCOL

INSLNS

LCAP

LCAPTA

LAMBDA

LIQL
Yearly total bank failure liabilities by state (Dun and Bradstreet) Brokered deposits

Predicted level of net-worth from net worth equation

Scaled version of predicted net worth/total asset

Core deposits - domestic deposits under $\$ 10,000$

Core deposits/Total Assets

$=1$ if bank is in a bank-holding company ( $=0$ otherwise)

$=1$ if state bank in a state with depositor preference legislation

$=1$ if bank's home state has statewide branching ( $=0$ otherwise)

if bank is in Boston, New York, or Philadelphia Fed districts

$=1$ if bank is in the Dallas Fed district

Annualized non-interest expense/Total Assets

Federal Fund sold (lent)

Federal Funds purchased (borrowed)

Foreign deposits + FFPURCH + OBM + BRKDEP

Predicted RESTYPE* Core Deposits

Interest income eamed on loans that is uncollected

Loans to insiders

Net worth lagged one call report

LCAP/Total Assets

Mills' ratio from failure equation (selectivity correction)

Hotfunds/Total Assets 
LIQLS

LNASST

LNBFLIAB

LNBFLIBD

LOANHERR

LPRBASD

NCRASSTA

NETCHARG

NETCHARGL

NETINCA

OBM

OBS

OBSLN

OBSOTHER

OBSTA

OREO

OREOA

OREOAS

PCI

PCID

PDNA

PDNAA

RESTYPE =
Scaled version of LIQL

Natural logarithm of total assets

Natural logarithm of BFLIAB

Scaled version of LNBFLIAB

Loan Herfindahl index (see Thomson [1992])

Logarithm of commercial problem bank assets (quarterly, scaled)

Risky assets not in OREO, PDNA, or INSLNS/Total Assets

Charge-offs minus recoveries (annualized)/Total Assets

Level of Charge-offs minus recoveries (annualized)

Annualized net income

Other borrowed money

Off-balance sheet items

Off-balance sheet loans

Off-balance sheet items other than loans

Off-balance sheet items/Total Assets

Other real estate owned

OREO/Total Assets

OREOAS scaled

Per capital income (by state, yearly)

Scaled PCI

Loans 90 days past-due or non-accruing

PDNA/Total assets

1 for purchase and assumptions or open bank assistance

$=0$ for Payouts, (Deposit Transfers; Liquidations) 
Table 4: OLS Estimation of Net Worth Equation

Ordinary least squares regression.

Observations $=12554$

Mean of LHS $=0.2574261 \mathrm{E}+05$

StdDev of residuals $=0.9529209 \mathrm{E}+04$

R-squared $=0.9983717 \mathrm{E}+00$

$\mathrm{F}[14,12539]=:-0.5491533 \mathrm{E}+06$

Log-likelihood $=-0.1328271 \mathrm{E}+06$

Amemiya Pr. Criter $=0.9091432 E+08$

ANOVA Source Variation

Regression $\quad 0.6981284 \mathrm{E}+15$

Residual $\quad 0.1138614 \mathrm{E}+13$

Total $\quad 0.6992671 \mathrm{E}+15$

Durbin-Watson stat. $=\quad 1.9899685$
Dep. Variable $=\mathrm{CAP}$

Weights $=$ ONE

Std.Dev of LHS $=0.2360194 \mathrm{E}+06$

Sum of squares $=0.1138614 \mathrm{E}+13$

Adjusted R-sq. $\quad=0.9983699 \mathrm{E}+00$

Prob value $\quad=0.3217295 \mathrm{E}-13$

Restr. $(b=0)$ Log-1 $=-0.1731268 \mathrm{E}+06$

Akaike Info.Crit. $=0.2116331 \mathrm{E}+02$

Degrees of Freedom Mean Square

14.

$0.4986632 \mathrm{E}+14$

12539. $0.9080583 \mathrm{E}+08$

$12553 . \quad 0.5570517 \mathrm{E}+11$

Autocorrelation $=0.0050158$

Variable Coefficient Std. Error t-ratio Prob. Mean \& S.D. of Var.

\begin{tabular}{lllllll}
\hline Constant & -1949.5 & 650.9 & -2.995 & 0.0027 & & \\
LCAP & 0.89404 & $0.3270 \mathrm{E}-02$ & 273.440 & 0.0000 & 25267.9 & 224028.21 \\
UNCOL & $0.89423 \mathrm{E}-01$ & $0.4122 \mathrm{E}-01$ & 2.169 & 0.0301 & 1246.4751 & 4056.5531 \\
PDNA & -0.10858 & $0.3539 \mathrm{E}-02$ & -30.679 & 0.0000 & 6066.3210 & 102138.91 \\
OREO & 0.28048 & $0.7553 \mathrm{E}-02$ & 37.135 & 0.0000 & 2599.6539 & 44808.083 \\
INSLNS & $-0.61862 \mathrm{E}-01$ & $0.2824 \mathrm{E}-01$ & -2.190 & 0.0285 & 421.5240 & 3261.1211 \\
NCRASST & $0.92774 \mathrm{E}-02$ & $0.5512 \mathrm{E}-03$ & 16.832 & 0.0000 & 164368.0289 & $\mathrm{n} / \mathrm{a}$ \\
OBS & $0.40403 \mathrm{E}-03$ & $0.1468 \mathrm{E}-04$ & 27.524 & 0.0000 & 598672.9122 & $\mathrm{n} / \mathrm{a}$ \\
COREDEP & $0.63920 \mathrm{E}-02$ & $0.3640 \mathrm{E}-03$ & 17.562 & 0.0000 & 192239.2570 & $\mathrm{n} / \mathrm{a}$ \\
NETCHRGL & $0.40950 \mathrm{E}-01$ & $0.8873 \mathrm{E}-02$ & 4.615 & 0.0000 & 2452.8385 & 34031.556 \\
LOANHERR & 0.36495 & 0.6996 & 0.522 & 0.6019 & 337.1351 & 123.7953 \\
HOTFUNDS & $0.19403 \mathrm{E}-03$ & $0.3088 \mathrm{E}-03$ & 0.628 & 0.5297 & 58972.1288 & $\mathrm{n} / \mathrm{a}$ \\
NETINCA & 0.13298 & $0.9252 \mathrm{E}-02$ & 14.373 & 0.0000 & 2190.141 & 25859.90 \\
BFLLAB & $-0.62394 \mathrm{E}-04$ & $0.2003 \mathrm{E}-04$ & -3.115 & 0.0018 & 2909409.8685 & $\mathrm{n} / \mathrm{a}$ \\
PCI & 90.466 & 35.62 & 2.540 & 0.0111 & 17.7465 & 2.4530
\end{tabular}


Table 5: Probit Estimation of Failure/Closure Equation for Selection in Resolution Cost Equation

Maximum Likelihood Estimates

Log-Likelihood.............. $\quad-897.79$

Restricted (Slopes=0) Log-L. $\quad-4047.1$

Chi-Squared (12)............ 6298.7

Significance Level........... 0.32173E-13

$\mathrm{N}(0,1)$ used for significance levels.

Variable Coefficient Std. Error t-ratio Prob. Mean \& S.D. of Var.

\begin{tabular}{lllllll}
\hline Constant & 9.1148 & 0.6272 & 14.533 & 0.0000 & & \\
CAPTAPS & -6.2946 & 0.1973 & -31.898 & 0.0000 & 0.9635 & 0.4444 \\
UNERNINC & 101.55 & 5.964 & 17.026 & 0.0000 & 0.0063 & 0.0050 \\
LIQL & -1.8881 & 0.4685 & -4.031 & 0.0001 & 0.0235 & 0.0744 \\
OBSTA & -0.25905 & 0.2271 & -1.141 & 0.2540 & 0.1158 & 0.8706 \\
INSIDELN & 10.566 & 1.889 & 5.593 & 0.0000 & 0.0052 & 0.0109 \\
LNASSTD & -2.5163 & 3.018 & -0.834 & 0.4044 & 0.1097 & 0.0126 \\
NCRASSTA & $-0.13310 \mathrm{E}-01$ & 0.2463 & -0.054 & 0.9569 & 0.5014 & 0.1439 \\
PCID & -13.393 & 1.320 & -10.149 & 0.0000 & 0.1775 & 0.0245 \\
LNBFLIBD & 3.9552 & 2.083 & 1.899 & 0.0576 & 0.1368 & 0.0170 \\
DBHC & -0.29586 & $0.7174 \mathrm{E}-01$ & -4.124 & 0.0000 & 0.7079 & 0.4547 \\
EFFICNCY & 0.93649 & 0.1339 & 6.997 & 0.0000 & 0.0382 & 0.0980 \\
COREDEPA & -5.0958 & 0.3436 & -14.832 & 0.0000 & 0.8472 & 0.1183
\end{tabular}

Frequencies of actual \& predicted outcomes

Predicted outcome has maximum probability.

Predicted

$\begin{array}{llll}\text { Actual } & 0 & 1 & \text { TOTAL }\end{array}$

$\begin{array}{rrrr}0 & 11251 & 63 & 11314 \\ 1 & 199 & 1041 & 1240\end{array}$

$\begin{array}{llll}\text { Total } & 11450 & 1104 & 12554\end{array}$ 
Table 8: Estimation of Resolution Cost Equation with Selection Equation Based on Failure/Closure

Two stage least squares regression. Observations $=1240$ Mean of LHS $=0.7785666 \mathrm{E}+04$ StdDev of residuals $=0.2826802 \mathrm{E}+05$ R-squared $=0.3763211 \mathrm{E}+00$ $\mathrm{F}[17,1222]=\cdot 0.4337303 \mathrm{E}+02$ Log-likelihood $=-0.1445978 \mathrm{E}+05$ Amemiya Pr. Criter $=0.8106805 \mathrm{E}+09$ Standard error corrected for selection..... Correlation of disturbance in regression and Selection Criterion (Rho). $\mathrm{N}(0,1)$ used for significance levels.

$$
\begin{aligned}
& \text { Dep. Variable }=\text { RESCOST } \\
& \text { Weights }=\text { ISQRTASS } \\
& \text { Std.Dev of LHS }=0.3580882 \mathrm{E}+05 \\
& \text { Sum of squares }=0.9764769 \mathrm{E}+12 \\
& \text { Adjusted R-squared }=0.3676447 \mathrm{E}+00 \\
& \text { Prob value }=0.3217295 \mathrm{E}-13 \\
& \text { Restr. }(\mathrm{b}=0) \text { Log-l }=-0.1476156 \mathrm{E}+05 \\
& \text { Akaike Info.Crit. }=0.2335126 \mathrm{E}+02
\end{aligned}
$$
$0.41150 \mathrm{E}-01$

Variable Coefficient Std. Error t-ratio Prob. Mean \& S.D. of Var.

\begin{tabular}{lllllll}
\hline Constant & -18520. & $0.1157 \mathrm{E}+05$ & -1.601 & 0.1094 & & \\
CAPPRED & -1.5649 & 0.2942 & -5.319 & 0.0000 & 1365.0043 & 13280.9120 \\
PRESTYPE & 848.73 & 4207. & 0.202 & 0.8401 & 0.8634 & 0.3436 \\
UNCOL & 4.0097 & 2.500 & 1.604 & 0.1087 & 372.8094 & 1223.6313 \\
PDNA & 1.2300 & 0.1881 & 6.539 & 0.0000 & 2919.4943 & 20213.7978 \\
OREO & 1.0600 & 0.1784 & 5.941 & 0.0000 & 1586.3624 & 8296.8723 \\
INSLNS & 2.4934 & 0.7669 & 3.251 & 0.0011 & 333.6080 & 1485.1996 \\
NCRASST & 0.39151 & $0.6641 \mathrm{E}-01$ & 5.895 & 0.0000 & 18067.5759 & 100641.7196 \\
OBS & $-0.42296 \mathrm{E}-01$ & $0.2372 \mathrm{E}-01$ & -1.783 & 0.0745 & 3950.4248 & 120213.8489 \\
COREDEP & -0.21267 & $0.3960 \mathrm{E}-01$ & -5.370 & 0.0000 & 28114.6640 & 106722.0044 \\
LNASST & 1810.7 & 1100. & 1.647 & 0.0996 & 9.8257 & 0.9672 \\
DPL & 3061.1 & 1798. & 1.703 & 0.0887 & 0.3025 & 0.4595 \\
FFSOLD & 0.31973 & $0.6417 \mathrm{E}-01$ & 4.982 & 0.0000 & 3393.2777 & 18981.2687 \\
FFPURCH & -0.32676 & $0.8033 \mathrm{E}-01$ & -4.067 & 0.0000 & 985.8246 & 49120.9834 \\
OBM & -0.17638 & 0.1760 & -1.002 & 0.3162 & 377.0792 & 16173.7663 \\
BRKDEP & -0.10775 & 0.1002 & -1.076 & 0.2821 & 1041.0330 & 11897.4723 \\
ICORE23 & $-0.23806 \mathrm{E}-01$ & $0.2632 \mathrm{E}-01$ & -0.904 & 0.3658 & 21341.9014 & 55330.3194 \\
LAMBDA & 1163.5 & 2359. & 0.493 & 0.6219 & 0.3339 & 0.6116
\end{tabular}


Table 9: The Impact of Depositor Preference Legislation on Resolution Costs

$$
\begin{array}{lll} 
& \text { Osterberg (1996) } & \text { Selection Model } \\
\text { O/T(1995) } & \text { 'Basic' plus DPL } & \begin{array}{l}
\text { with Predicted } \\
\text { Res.Type }
\end{array}
\end{array}
$$

$\begin{array}{llll}\text { constant } & 69842(13394)^{* *} & -10270(10420) & -18520(11570) \\ \text { CAP1 } & -1.165(0.0720)^{* *} & -1.1730(0.2222)^{* *} & -1.5649(0.2942)^{* *} \\ \text { UNCOL } & 4.376(0.893)^{* *} & 4.9476(2.519)^{* *} & 4.0097(2.500) \\ \text { PDNA } & 0.786(0.049)^{* *} & 1.0920(0.1712)^{* *} & 1.2300(0.1881)^{* *} \\ \text { OREO } & 0.453(0.0560)^{* *} & 0.52367(0.1593)^{* *} & 1.0600(0.1784)^{* *} \\ \text { INSLNS } & 1.775(0.276)^{* *} & 2.4705(0.7709)^{* *} & 2.4934(0.7669)^{* *} \\ \text { NCRASST } & 0.202(0.020)^{* *} & 0.31395(0.0571)^{* *} & 0.3915(0.0664)^{* *} \\ \text { OBSLN } & -0.158(0.016)^{* *} & & \\ \text { OBSOTHER } & -0.038(0.007)^{* *} & & \\ \text { OBS } & & -0.0167(0.0219) & -0.0423(0.0237)^{*} \\ \text { FFSOLD } & & 0.3052(0.0609) * * & 0.3197(0.0642)^{* *} \\ \text { FFPURCH } & & -0.3505(0.0708)^{* *} & -0.3268(0.0803)^{* *} \\ \text { COREDEP } & -0.088(0.010)^{* *} & -0.2027(0.0370)^{* *} & -0.2127(0.0396)^{* *} \\ \text { ICORE1 } & 0.062(0.010)^{* *} & 0.0384(0.0241) & -0.0238(0.0263) \\ \text { LNASST } & & 1145.0(1098.0) & 1810.7(1100)^{*} \\ \text { BRKDEP } & -0.095(0.034)^{* *} & -0.0809(0.0952) & -0.1078(0.1002) \\ \text { DUMNE } & 5856.9(1692.8)^{* *} & 5673.9(5009) & \\ \text { DUMSW } & 1345.0(593.1)^{* *} & 8.9151(1969) & \\ \text { DPL } & & 2826.6(1967) & 3061.1(1798)^{*} \\ \text { OBM } & & & -0.1764(0.1760) \\ \text { PRESTYPE } & & & 848.73(4207) \\ \text { LAMBDA } & & & 1163.5(2359) \\ \text { \# Observations } & & 1240 & 1240 \\ \text { Adj. R } & & 0.3692 & 0.3727\end{array}$

Notes:

Standard errors are in parentheses.

Observations are weighted by one divided by the square root of total assets.

The first column is from the Table 3, Osterberg and Thomson (1995). The second column is unreported, referenced in from Osterberg (1996).

* : significant at the $10 \%$ level.

**: significant at the $5 \%$ level.

1 Results in third column use predicted capital and resolution type. 
Appendix A

Adjustment of Standard Errors for Inclusion of Predicted Values as Regressors

We follow Murphy and Topel (1985) in deriving the correct standard errors when one or more variables on the right-hand side of either the failure/closure, resolution type, or resolution cost equation has been generated by a prior estimation. In the case of the failure/closure equation, and the resolution type equation, which are estimated by probit (maximum likelihood [MLE]), the right-hand side includes the predicted value of net worth/total assets, which was generated by ordinary least squares (OLS). In the case of resolution cost, the right-hand side includes the predicted level of net worth, estimated by OLS, and the predicted resolution type, predicted by probit (MLE).

Murphy and Topel present the correct adjustment when the first stage estimation is maximum likelihood and the second MLE or when both are MLE. Here we detail the derivation for the slightly different case when the first stage is OLS and the second MLE.

The OLS estimation yields:

$\sqrt{n}\left(\hat{\theta}_{1}-\theta_{1}^{*}\right)=\left(\frac{1}{n} X_{1}^{\prime} X_{1}\right)^{-1} \frac{1}{n} X_{1}^{\prime} U_{1}$, where $X, \mathrm{U}$, and $\theta$ denote the right-hand side variables, estimated residuals, and parameters, respectively.

The MLE estimation yields:

$$
\begin{aligned}
& -\frac{1}{\sqrt{n}} \sum \frac{\partial \ell_{2}\left(y_{2}, \theta_{1}^{*}, \theta_{2}^{*}\right)}{\partial \theta_{2}}=\frac{1}{n} \sum \int_{0}^{1} \frac{\partial^{2} \ell_{2}\left(\theta_{1}^{*}+\lambda\left(\hat{\theta}_{1}-\theta_{1}^{*}\right)\right) d \lambda}{\partial \theta_{2} \partial \theta_{1}^{*}} \sqrt{n}\left(\hat{\theta}_{1}-\theta_{1}^{*}\right) \\
& +\frac{1}{n} \sum \int_{0}^{1} \frac{\partial^{2} \ell_{2}\left(\theta^{*}+\lambda\left(\hat{\theta}_{2}-\theta_{2}^{*}\right)\right) d \lambda}{\partial \theta_{2} \partial \theta_{2}^{\prime}} \sqrt{n}\left(\hat{\theta}_{2}-\theta_{2}^{*}\right)
\end{aligned}
$$

where $\ell_{2}$ denotes the log-likelihood for the second equation, $\theta_{2}$ denotes the parameters in the second equation (including those associated with the predicted values from prior equations).

Substitution yields:

$\sqrt{n}\left(\hat{\theta}_{2}-\theta_{2}^{*}\right) \cong-R_{2}^{-1}\left\{\frac{1}{\sqrt{n}} \sum_{i=1}^{n} \frac{\partial \ell_{2}\left(y_{2}, \theta_{1}^{*}, \theta_{2}^{*}\right)}{\partial \theta_{2}}\right\}+R_{2}^{-1} R_{3}^{\prime}\left(\frac{1}{n} X_{1}^{*} X_{1}\right)^{-1} \frac{1}{\sqrt{n}} X_{1}^{\prime} U_{1}$,

where $R_{2}$ is Fisher's information matrix which can be written as 
$-E\left[\partial^{2} \ell_{2} / \partial \theta_{2} \partial \dot{\theta}_{2}\right]$ and will be easily retrieved from the estimation of the second equation. ${ }^{1} R_{3}$ must be derived and is equal to $-E\left\{\frac{\partial \ell_{2}}{\partial \theta_{2} \partial \theta_{1}}\right\}$.

Then we need the form of the variance-covariance matrix $\Omega$ where $\frac{1}{\sqrt{n}}\left[\begin{array}{c}\sum_{i=1}^{n} \partial \ell_{2} / \partial \theta_{2} \\ \sum_{i=1}^{n} X_{1}^{\prime} U_{1}\end{array}\right] \equiv \mathrm{N}(0, \Omega)$ and $\Omega=\left[\begin{array}{cc}-\frac{1}{n} E \frac{\partial^{2} \ell_{2}}{\partial \partial \partial \theta} & E \sum \frac{\alpha_{2}}{\partial \theta_{2}} U_{1}^{\prime} X_{1} \\ E \sum X_{1}^{\prime} U_{1} \frac{\partial}{\partial \theta_{1}} & \frac{1}{n} \sigma^{2}\left(X_{1}^{\prime} X_{1}\right)\end{array}\right]$.

Then, for the estimated parameters for the second equation $\left(\hat{\theta}_{2}\right)$ we have $\sqrt{n}\left(\hat{\theta}_{2}-\theta_{2}^{*}\right)=\mathrm{N}(0, \Sigma)$ where $\Sigma=R_{2}^{-1}+R_{2}^{-1}\left[R_{3}^{\prime} \sigma^{2}\left(X_{1}^{\prime} X_{1}\right)^{-1} n R_{3}+Q_{2}^{\prime} Q_{0}^{-1} R_{3}+R_{3}^{\prime} Q_{0}^{-1} Q_{2}\right] R_{2}^{-1}$ where $R_{2}$ and $R_{3}$ are defined as above, $Q_{2}$ is the lower-left hand quadrant of $\Omega$, and $\hat{Q}_{0}=\frac{1}{n}\left(X_{1}^{\prime} X_{1}\right)^{-1}$, which is easily retrievable from the results of the first-stage OLS estimation.

For the standard error adjustment for both the failure and resolution type equations, the log-likelihood is based on the bivariate probit as discussed by Greene (1993). As mentioned in the text, since neither the failure dummy nor the resolution type dummy appears in the other's equation, while the failure equation supplies the selection rule for the resolution type equation, the two are better thought of as an ordered probit. However, although there is no simultaneity the presence of selectivity implies that $\rho \neq 0$.

\footnotetext{
${ }^{1}$ Given that the failure/closure and resolution type equations are estimated as an ordered probit, $R$ is retrieved as the appropriate quadrant of the variance covariance matrix from the two equations
} 


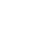





\section{Federol Reserve Bank}

of Clevelond

Research Deportment

P.O. Box 6387

Clevelond, $\mathrm{OH} 44101$

Address Correction Requested:

Pleose send corrected moiling label to the Federal Reserve Bank of Cleveland,

Research Department,

P.O. Box 6387,

Clovelond, $\mathrm{OH} 44101$ 